\title{
BE GODOGAN \\ KULINER TRADISIONAL BALI di AMBANG KEPUNAHAN
}

\author{
A.A Ketut Sri Candrawati dan Ni Nyoman Widani \\ Email: sri.candrawati@pib.ac.id dan wiwin_widani@yahoo.com \\ POLITEKNIK INTERNASIONAL BALI
}

\begin{abstract}
Abstrak
Salah satu Kuliner Tradisional Bali (KTB) yang hampir punah adalah Be Godogan (daging kodok sawah). Tujuan penulisan artikel ini adalah untuk mendeskripsikan gastronomi be godogan Bali dan memperoleh strategi untuk mempertahankan eksistensi sumber daya hayati bahan utama be godogan. Untuk mencapai tujuan digunakan teori gastronomi dan teori budi daya. Teknik pengumpulan data yang digunakan dalam penelitian ini adalah wawancara dan studi pustaka.

Hasil penelitiaan menunjukkan bahwa be gedogan memiliki sumber protein hewani yang tinggi, rasanya enak, sehingga disejajarkan dengan daging ayam. Sebagian orang percaya daging kodok dapat menyembuhkan beberapa penyakit dan meningkatkan vitalitas laki-laki. Cara perawatan tanaman di sawah dengan pestisida telah mengancam kehidupan kodok sawah ini dan populasinya menurun drastis. Strategi mempertahankan eksistensi sumber daya hayati bahan utama be godogan adalah dengan dilakukannya peternakan kodok untuk keberlangsungan dari KTB ini.
\end{abstract}

Kata kunci: kuliner tradisional, be gedogan, kepunahan, Bali.

\section{Abstract \\ One of the almost extinct BTC is Be Godogan (rice field frog} meat). The purpose of this article is to describe the gastronomy of the Balinese cuisine and obtain a strategy to maintain the existence of its main ingredients. To achieve the goal, gastronomic theory and the theory of cultivation are used. The data collection technique used in this study is through interviews and literature study.

The results of the research show that be gedogan has a high source of animal protein and tastes, so it is aligned with chicken meat. Some people believe that frog meat can cure several diseases and increase male vitality. The use of pesticides in processing rice fields has threatened the life of this frog as it has dramatically dropped its population. The strategy to maintain the existence of the biological resources is to preserve rice field frogs for the continuity of this BTC.

Keywords: traditional culinary, be gedogan, extinction, Bali. 


\section{Pendahuluan}

Kuliner Tradisional Bali (KTB) biasanya memiliki nilai tradisi dan citarasa yang tinggi, hal ini tampak dari berbagai hidangan khusus untuk banten atau sesajen dibuat dengan bentuk, warna dan rangkaian simbolsimbol yang memiliki makna kompleks. Tradisi dari kuliner tersebut menciptakan keindahan dan kekaguman sebagai salah satu daya tarik wisatawan. Sama halnya dengan Kuliner Tradisional lainnya, KTB juga memiliki ciri-ciri umum dengan rasa yang kuat dan tajam, karena banyak bumbu yang digunakan, terutama bumbu-bumbu yang disebut base genep (Ariani, 2017: 17-18).

Base genep terdiri dari berbagai macam rempah dan bumbu, sehingga memiliki ketajaman rasa, dan juga rasa pedas cabai sangat terasa. Bahan bumbu yang digunakan merupakan bahan pangan lokal yang banyak dihasilkan di daerah setempat, demikian pula dengan peralatan tradisional dibuat dari bahan-bahan alam yang ada di sekitar oleh masyarakat setempat. Selain itu, cara pengolahan dan penyajian makanan juga masih sangat tradisional, bahkan setiap daerah di Bali memiliki ciri khas yang berbeda satu daerah dengan daerah lainnya. Semua proses pengadaan makanan ini sampai dengan penyajiannya memiliki ciri khas yang sangat erat hubungannya dengan budaya dan kepercayaan Agama Hindu.

Walau umumnya KTB dikenal memiliki rasa kuat dan tajam berasal dari bumbu basa genep, tetapi tidak jarang banyak ditemui jenis makanan tradisional harian masyarakat Bali yang memiliki rasa sangat sederhana dengan bumbu yang sangat sederhana, bahkan ada yang hanya berbumbu garam saja atau ditambah dengan ulekan kencur (cekuh) dan bawang putih (kesuna), namun tetap terasa gurih. Salah satu KTB yang memiliki bumbu sangat sederhana namun rasanya tetap gurih walau tidak memakai bumbu basa genep adalah Be Godogan (daging kodok hijau sawah) yang digoreng sampai garing. 


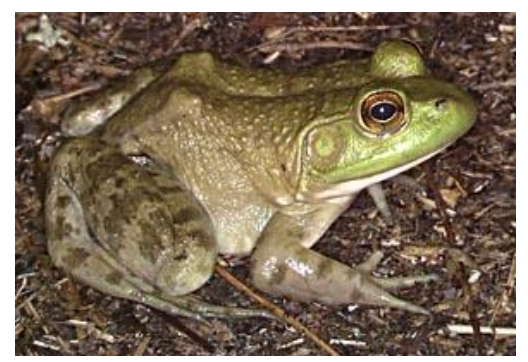

Gambar 1. Kodok Yang Sudah Hampir Dewasa

Sumber: http://jualkodok.blogspot.com/2012/07/kodok-hijau.html

Kodok atau katak (bahasa Inggris: frog) adalah binatang amfibi pemakan serangga yang bisa hidup di air tawar atau di daratan, berkulit licin, berwarna hijau atau merah kecoklat-coklatan, kaki belakang lebih panjang dari kaki depannya, pandai melompat dan berenang. Katak hijau sawah yang sudah besar di Bali disebut godogan, yang sering ditangkap oleh para petani sebagai menu kuliner harian, terutama pada musim penghujan.

Namun sejalan dengan perubahan ekosistem lingkungan dalam sistem pertanian di Bali, telah berdampak besar yang menyebabkan langkanya populasi kodok hijau di sawah. Di tahun 1980-an kodok hijau sawah pernah menjadi obyek buruan besar-besaran untuk dijadikan komoditi ekspor ke luar negeri, khususnya ke Taiwan. Namun intensifikasi sistem pertanian yang mengarah pada penggunaan bahan-bahan kimia beracun dalam perawatan tanaman padi di sawah pada periode kemudian membawa dampak secara berangsur-angsur pada populasi kodok hijau yang menjadi semakin langka. Bahkan kini, jangankan sampai untuk ekspor daging kodok, hanya untuk kebutuhan konsumsi masyarakat petani sendiri saja sudah sangat langka.

Berdasarkan latar belakang masalah di atas maka dapat dirumuskan beberapa masalah berkaitan dengan menu kuliner khas Bali dari bahan utama Be Godogan (daging kodok hijau sawah), yaitu: 1) Bagaimanakah 
gambaran gastronomi be godogan Bali dan 2) Bagaimanakah strategi mempertahankan eksistensi sumber daya hayati bahan utama be godogan?

\section{Teori dan Metode}

Teori yang digunakan untuk memecahkan pokok permasalahan adalah teori gastronomi merupakan seni atau ilmu terhadap kenikmatan sebuah makanan dan minuman (Scarpato, 2002:36). Teori tersebut digunakan untuk mengkaji kuliner be gedogan. Teori budi daya adalah usaha yang dilakukan di suatu tempat tertentu pada suatu kawasan budi daya secara berkesinambungan untuk hewan peliharaan dan produk hewan. Hewan yang dijadikan fokus adalah kodok atau katak, hewan ini dibudidayakan namun masuk dalam hewan yang diternak. Teori ini dipergunakan untuk mengkaji strategi mempertahankan eksistensi sumber daya hayati bahan utama be godogan.

Penelitian ini memakai pendekatan holistik berarti cara melihat atau memandang sesuatu sebagai suatu kebulatan yang utuh. Teknik pengumpulan data melalui wawancara dan studi pustaka. Jenis penelitian adalah deskriptif analitis (descriptive analitic) yang bertujuan untuk memeroleh secara jelas tentang suatu situasi atau keadaan tertentu yang ada di lapangan melalui pengumpulan data, dalam hal ini khususnya cara membuat kuliner yang sudah langka ini dan kaitannya dengan penyebab terjadinya keterbatasan potensi pasokan bahan alam dan hayati yang ada di daerah Bali saat ini.

\section{Pembahasan}

Pada pembahasan akan dibahas mengenai hasil dari penelitian dan menjawab kedua masalah yang ada dalam penelitian ini. Lebih lengkapnya dapat dilihat di bawah ini. 


\subsection{Gambaran Gastronomi Be Godogan Bali}

Gambaran gastronomi be gedogan akan dijelaskan dari lingkungan kuliner, kandungan gizi, sejarah, bahan dan bumbu masakan, cara membuat, cara memasak, cara penyajian hingga waktu penyajian kuliner.

\section{Lingkungan lokasi Be Godogan Goreng}

Lingkungan lokasi be godogan sering ditemukan di sekitar kehidupan komunitas masyarakat petani pedesaan. Be godogan bisa menjadi salah satu masakan atau kuliner khas harian dari lingkungan pedesaan yang banyak areal persawahan dan sungai yang bersemak di Bali. Hal ini mengingat dari habitat hidup godogan adalah makhluk amfibi yaitu makhluk yang dapat hidup di dua ekosistem berbeda (darat yang bersemak dan air). Kodok dan katak hidup di daerah tropis yang berhawa panas. Makin dingin tempatnya, seperti di atas gunung atau di daerah yang memiliki empat musim (bertemperatur dingin), jumlah jenis kodok cenderung semakin sedikit. Salah satunya karena kodok termasuk hewan berdarah dingin, yang membutuhkan panas dari lingkungannya untuk memertahankan hidup dan menjaga metabolisme tubuhnya.

Katak dan kodok berbeda dengan dongkang (bangkong kolong), yang merupakan salah satu jenis katak yang kerapkali ditemui di pojok-pojok rumah atau di balik pot di halaman. Berbeda pula dengan emplegan (katak pohon) yang menghuni pohon-pohon rendah dan semak belukar, terutama di sekitar saluran air atau kolam. Kodok memangsa berbagai jenis serangga yang ditemuinya. Di malam hari kodok kerap keluar dari semak dan berkerumun di bawah cahaya lampu jalan atau taman, menangkap serangga-serangga yang tertarik oleh cahaya lampu. Sebaliknya, kodok sering dimangsa oleh ular, kadal, burung-burung, seperti bangau, elang, garangan, linsang, dan 
dikonsumsi oleh manusia. Itu berkaitan dengan rantai makanan dalam ekosistem alam semesta.

\section{Kandungan Gizi Be Godogan}

Godogan (kodok) sebagai bahan makanan yang biasa dikonsumsi oleh masyarakat Indonesia dan khususnya masyarakat petani pedesaan di Bali memiliki kandungan berbagai elemen nutrisi yang banyak dibutuhkan oleh tubuh manusia. Penelitian terhadap 100 gram kodok, dengan jumlah yang dapat dimakan sebanyak $65 \%$, mengandung energi sebesar 73 kilo kalori, protein 16,4 gram, karbohidrat 0 gram, lemak 0,3 gram, kalsium 18 miligram, fosfor 147 miligram, dan zat besi 1 miligram. Selain itu di dalam Kodok juga terkandung vitamin A sebanyak 0 IU, vitamin B1 0,14 miligram dan vitamin C0 miligram (http://www.organisasi.org/19 70/01/isikandungan-gizi-kodok-komposisi-nutrisi-bahan-makanan. html\#.W1loH_lTLcs).

Daging kodok adalah sumber protein hewani yang cukup tinggi, yang juga dipercaya dapat menyembuhkan beberapa penyakit, di antaranya dapat digunakan untuk mengatasi penyakit kanker. Dr Willie menggunakan lendir katak sebagai material pengobatan alternatif untuk penyakit kanker. Melalui media infus, pengobatan ini bersifat seperti kemoterapi pada umumnya, karena ramuannya mengandung cinobufacini (lendir katak).

Daging kodok terutama jenis kodok batu, juga digunakan sebagai menu obat alternatif yang berkhasiat untuk mengatasi infertilitas pria. Ada beberapa pilihan menu obat alternatif kodok, bisa diblender menjadi jus, seperti yang dilakukan orang-orang Peru yang disebut 'Extracto de rana' (jus kodok) yang sangat terkenal dengan julukan "Viagra dari Peru". Tetapi jika tidak sanggup minum model "Viagra Peru" tersebut, bisa dicoba alternatif kedua, dengan mengolah daging 
kodok batu yang telah dipotong-potong dan dicampur dengan irisan tipis-tipis satu papan petai, lima siung bawang putih, potongan kecilkecil dua ekor ayam, serta 24 butir merica yang digiling lembut. Semua bahan tersebut direbus selama 20 menit dalam air kemudian ditambahkan garam dan angkat, tunggu hingga tidak terlalu panas, kemudian tambah dua sendok teh madu asli dan dimakan setiap pagi hari.

Resep di atas berguna untuk mengoptimalkan fungsi ginjal pada pria produktif agar kualitas sperma menjadi baik. Membuat sperma jadi lebih kental dan merupakan alternatif obat untuk mani encer (http://detiklife.com/tag/kandungan-gizi-daging-kodok/).

\section{Sejarah Be Godogan Goreng}

Sejarah lahirnya be godogan diduga berasal dari kreatifitas kehidupan para petani sawah di pedesaan. Pada masa lampau, masyarakat petani di pedesaan, pada malam hari, sewaktu musim tanam padi, punya banyak waktu luang untuk mencari kegiatan alternatif dalam memenuhi kebutuhan bahan lauk harian, salah satunya adalah dengan menangkap kodok di parit-parit sawah atau saluran air atau sungai di sekitar pedesaan, untuk meringankan pengeluaran keuangan keluarga. Kegiatan ini disebut dengan nyuluh (menerangi pakai lampu stronking) tempat kehidupan kodok agar bisa ditangkap.

Sambil jalan, tangan kiri menenteng lampu stronking sedangkan tangan kanan memegang parang panjang atau tombak khusus kodok, dan dungki (kantong penyimpanan kodok dari anyaman serat bambu) terikat di pinggang. Cukup berbekal parang yang cukup panjang, bila sudah ketemu kodok dengan mengintip langsung dipotong (dipukul) pakai parang bagian badannya sampai mati, lalu dimasukan ke dungki. Alat yang lebih bagus adalah memakai tombak khusus yang 
ujungnya tajam bermata dua dan bertangkai cukup panjang (sekitar 2-3 meter) sehingga tidak perlu susah mengendap mengintipnya dari dekat. Cukup membidiknya dengan ujung mata tombak dari jauh dan menombak badan katak di pinggir semak sampai tembus, selanjutnya dilepas pakai tangan untuk dimasukan ke dungki (Wawancara Made Kesiar, 27 Juli 2017).

Cara lain yang bisa dilakukan siang hari yaitu dengan cara memancing kodok di semak dekat parit persawahan. Jenis aktivitas memancing ini dapat dilakukan dengan tiga cara. Umpan mancing kodok adalah menggunakan katak (anak kodok) seperti yang sering dipakai waktu berburu ikan kulen atau julit (sidat atau segala jenis ikan predator). Dengan mengacungkan katak yang terikat di kail tali pancing ke semak maka kodok akan terangsang untuk menangkap mangsanya. Kodok bersifat kanibal (suka memangsa sesama anak sendiri). Tetapi tujuan umpan mancing kodok dengan dikail hanya sekedar untuk memancing kodok keluar dari persembunyiannya di semak tepi kali atau parit sawah. Jadi, pancing bersama kail kataknya itu hanya diacung-acungkan ke dalam semak untuk menarik perhatian kodok terhadap mangsanya di kail. Setelah kodok terpancing kail diangkat keluar semak sampai kodok melompat keluar mengejar mangsanya di kail. Setelah kena tipu kodok ditangkap dengan jaring berlubang bulat kecil dan bertangkai cukup panjang, atau yang lebih sederhana dengan kau (baskom kecil dari setengah potong tempurung kelapa yang sudah dibersihkan bagian serabutnya). Pengunaan kail untuk menusuk katak sebenarnya hanya berfungsi untuk memerkuat pegangan terhadap katak sebagai umpan. Bisa saja dengan cara lebih sederhana katak diikat sedemikian rupa dengan tali saja di tali pancing. Gunanya hanya sekedar sebagai pengalih perhatian kodok terhadap mangsa untuk keluar dari sarangnya di semak, sehingga 
mudah dilihat untuk ditangkap dengan jaring atau perangkap kau (tutup dari atas).

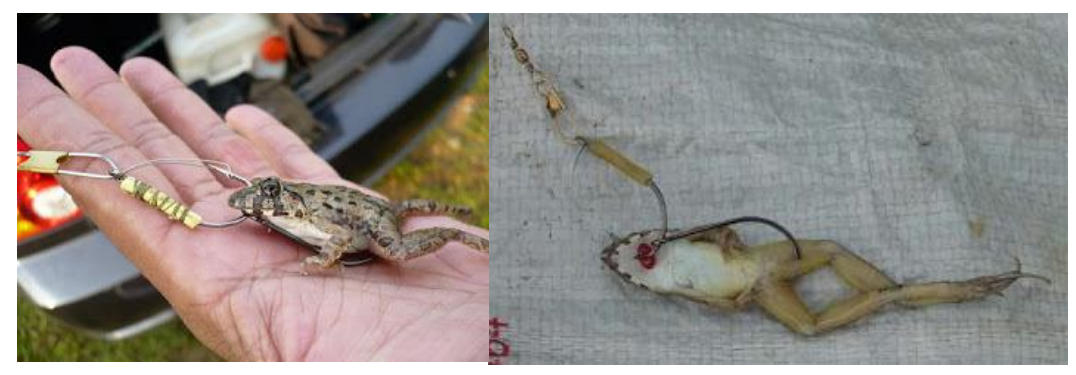

Gambar 2. Cara Memasang Umpan Katak

Sumber: http://jagoanmancing.blogspot.com/2013/02/cara-memasang-umpankatak.html

Terdapat cara untuk memasang umpan katak, yaitu perlu disiapkan katak anakan yang berukuran tidak terlalu gede. Biasanya hidup di sawah yang baru saja dicangkul atau baru akan ditanami benih padi. Persiapkan kail (mata pancing), bisa memakai dua kail. Satu ditancapkan di mulut satu lagi di badan katak. Sebagai alternatif, bisa menggunakan kail dan klip. Penggunaan kail dan klip akan lebih simpel, efektif, dan praktis. Namun itu semua terserah pilihan masing-masing. Untuk lebih jelasnya lihat foto cara masang umpan katak di atas ini.

\section{Bahan dan Bumbu Be Godogan Goreng (Swieke)}

Bagi yang menyukai masakan ala Tiongkok tentu pernah merasakan kelezatan swieke yang banyak disukai orang. Budaya makan kodok tidak hanya terdapat di Eropa, di Asia juga punya kultur memakan makanan berbahan baku daging kodok. Di Tiongkok, diperkirakan kaki kodok sudah disantap sejak abad ke 1. Indonesia juga punya kuliner berbahan baku kodok swieke. Ada pula yang menulisnya swike. Istilah itu berasal dari bahasa Hokkian. Swi berarti air, $k e$ berarti ayam. Diperkirakan ini adalah penggambaran tentang bagaimana rasa dan tekstur daging kodok mirip dengan daging ayam. 
Namun konsumsi kodok di Indonesia tentu tak sebanyak di Eropa atau di Taiwan, sebab mayoritas warga Indonesia adalah umat Islam yang menganut mazhab Syafi'i yang mengharamkan daging kodok. Beda dengan masyarakat Bali yang beragama minoritas Islam dan mayoritas beragama Hindu, sering menjadikan kodok sebagai lauk harian pilihannya.

Bahan-bahan be godogan untuk satu porsi adalah: empat ekor kodok besar dipotong bagian kepala, lalu pelet (kuliti) dan pisahkan kulitnya, tiga sendok makan mentega, tiga butir putih telur, tepung Putri secukupnya, garam secukupnya, dan minyak goreng secukupnya kurang lebih satu sendok makan mentega untuk menggoreng. Bumbu lain yang digunakan untuk membuat $B e$ Godogan adalah: satu buah jeruk nipis, satu buah jeruk limau, kecap ikan secukupnya, dan maggie seasoning secukupnya (https://cook pad.com/id/resep/4979147-kodok-goreng-tepung91-\%8-D?-via=se$\operatorname{arch})$.

\section{Cara Membuat}

Pembuatan Be Godogan terdiri dari empat tahapan. Pertama cuci bersih kodok tiriskan dan demikian juga kulitnya. Setelah itu, kodok dibelah menjadi 3 bagian, untuk pisahkan paha, dada dan kaki depan (tangan). Langkah selanjutnya, bagian daging paha diiris serong supaya bumbunya cepat meresap dan cepat matang. Dan langkah terakhir adalah melumuri semua bagian dengan jeruk nipis, kecap, beri maggie seasoning secukupnya dan taburi sedikit garam, lalu remas-remas. Ambil kulitnya satukan untuk diberi bumbu yang sama, lalu diremas dan masukkan freezer sebentar. 


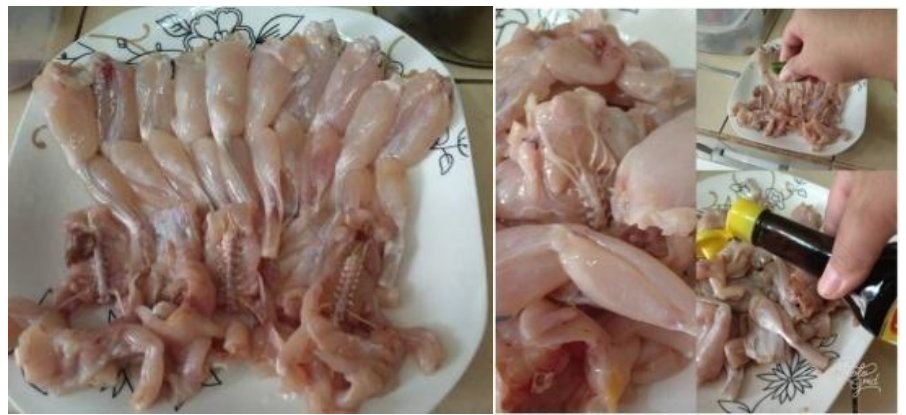

Gambar 3. Cara Membuat Kodok Goreng

Sumber foto: https://cookpad.com/id/step/images/7731022c89326a57

\section{Cara Memasak}

Memasak kodok goreng, langkah-langkahnya adalah sebagai berikut: tuang minyak goreng secukupnya (perkirakan sampai daging kodok terendam) kurang lebih satu sendok makan mentega, lalu panaskan sampai minyak mendidih. Lalu sambil daging kodok dari freezer, lalu lumuri putih telur, dan balut dengan tepung Putri, bolak balik langsung digoreng dengan api sedang sampai matang.

Langkah ketiga, goreng secara bertahap diamkan satu sisi kemudian baliknya sampai matang, tapi jangan terlalu kering sekali atau menjadi keras. Setelah bagian pertama benar-benar matang lalu angkat tiriskan. Lanjutnya bagian berikutnya sampai selesai. Terakhir, kulitnya digoreng tanpa di balur apapun sampai crunchy, lalu angkat.

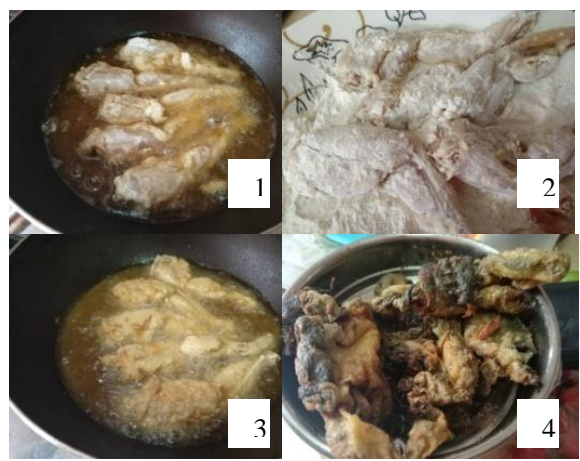

Gambar 4. Cara Membuat Kodok Goreng

Sumber foto: https://cookpad.com/id/resep/4979147-kodok-gorengtepung $91 \% 8 \mathrm{D}$ ? via=search 
Kerupuk kulit kodok ini adalah bagian ternikmat. Berikut dapat dilihat gambar petunjuk cara memasak kodok goreng. Sajikan daging kodok dengan perasan jeruk limau. Rasanya empuk, crispy, dan sangat harum aroma masakan ini. Kodok goreng ini juga bisa disajikan dengan sambal tomat.

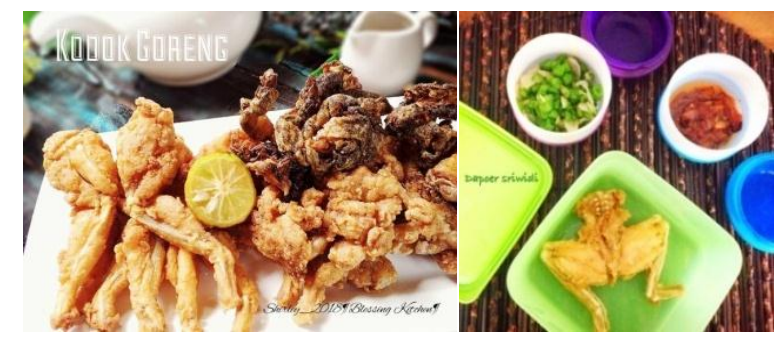

Gambar 5. Cara Penyajian Kodok Goreng

Sumber foto: https://i.ytimg.com/vi/w47Ea5xkoYc/maxresdefault.jpg

\subsection{Strategi Mempertahankan Sumber Daya Hayati Bahan Utama Be Godogan}

Strategi yang dapat dilakukan oleh pemerintah maupun masyarakat untuk mempertahankan sumber daya hayati bahan utama be godogan, yaitu dengan budi daya. Budi daya adalah "usaha yang bermanfaat dan memberi hasil". Kegiatan budi daya ada budi daya tanaman dan budi daya hewan (husbandry). Budi daya hewan melibatkan usaha pembesaran bakalan (hewan muda) atau bibit/benih (termasuk benur dan nener pada budi daya perikanan) pada suatu lahan tertentu selama beberapa waktu untuk kemudian dijual, dimanfaatkan dagingnya, telurnya, atau diperah susunya (pada peternakan susu). Proses pengolahan produk budi daya ini biasanya bukan bagian dari budi daya sendiri tetapi masih dianggap sebagai mata rantai usaha tani ternak itu. Budi daya hewan dikategorikan ke dalam peternakan dan budi daya perikanan (https://id.wikipedia.org/ wiki/Budi_daya).

Peraturan Presiden Republik Indonesia No 48 Tahun 2013 Tentang Budi Daya Hewan Peliharaan adalah "usaha yang dilakukan di suatu 
tempat tertentu pada suatu kawasan budi daya secara berkesinambungan untuk hewan peliharaan dan produk hewan". Pada penelitian ini yang akan dibudidayakan adalah kodok yang merupakan bahan utama dalam membuat kuliner be godogan. Untuk kodok yang dibudidayakan termasuk diternak, hal ini disebabkan kodok termasuk hewan ternak.

Hewan ternak dapat dibagi atas dua golongan, yaitu peternakan hewan besar seperti sapi, kerbau dan kuda, sedang kelompok kedua yaitu peternakan hewan kecil seperti ayam, kelinci, dan kodok (https://id.wikipedia.org/wiki/Peternakan).

Ternak Kodok, Kodok hijau (Rana catesbeiana) atau lebih dikenal oleh masyarakat sebagai kodok sawah adalah kodok yang hidup di sawah. Kodok kini telah banyak diternakkan di Indonesia dan juga di Negaranegara lain seperti Tiongkok, Bangladesh, Turki, India, dan Hongkong. Kodok termasuk dalam golongan binatang amfibi tanpa ekor (hewan ordo Anura). Kodok hijau termasuk kodok asli dari Indonesia, tapi ada juga yang memperkirakan awalnya berasal dari Taiwan. Indonesia memiliki tiga jenis kodok asli selain kodok hijau yang banyak di komsumsi oleh masyarakat, yaitu: 1) Rana Musholini (kodok batu/raksasa), terdapat di Sumatera, terutama Sumatera Barat dengan berat mencapai $1.5 \mathrm{~kg}$ panjang $22 \mathrm{~cm}, 2)$ Rana Limnocharis (kodok rawa), dagingnya paling enak, ukurannya hanya $8 \mathrm{~cm}, 3$ ) Rana Cancrivora (kodok sawah), badannya mencapai $10 \mathrm{~cm}$, badan berbercak coklat, 4) Rana Macrodon (kodok hijau), yang berwarna hijau dan dihiasi totol-totol coklat kehijauan dan tumbuh mencapai $15 \mathrm{~cm}$.

Persyaratan lokasi yang ideal untuk ternak kodok adalah 1600 di atas permukaan laut (dpl). Tanah dengan kemiringan ideal 1-5\%, artinya dalam jarak $100 \mathrm{~m}$ jarak kemiringan antara ujung-ujungnya 1-5 m. Air jernih tersedia sepanjang masa. Air yang jernih akan memperlancar proses penetasan telur. Kodok bisa hidup di air yang bersuhu $2-35^{\circ}$ C. Suhu saat 
penetasan telur ialah antara $24-27^{\circ} \mathrm{C}$, dengan kelembaban $60-65 \%$. Air harus mengandung oksigen sekitar 5-6 ppm atau minimum 3 ppm. Karbon dioksida terlarut tidak lebih dari $25 \mathrm{ppm}$, bebas dari kekeringan dan kebanjiran.

\section{Penutup}

Bagi sebagian orang, kodok atau katak merupakan binatang yang menjijikkan. Namun, ada di antara jenis kodok yang bernilai ekonomis tinggi karena dapat dimakan, yakni kodok hijau atau kodok sawah atau kodok lembu. Kodok ini biasa hidup di alam bebas, namun dapat diternakkan. Kodok hijau, walau tidak termasuk komoditas unggulan, namun kodok hijau pernah menjadi salah satu komoditas ekspor Bali di tahun 1980-an. Kondisi alam yang tidak mendukung setelah periode kemudian membuat jumlah ekspor kodok hijau dari Bali mengalami kemunduran bahkan tidak ada terdengar beritanya lagi.

Daging kodok adalah sumber protein hewani yang tinggi kandungan gizinya, rasanya enak sehingga disejajarkan dengan daging ayam sehingga disebut swieke oleh orang Taiwan. Banyak warga Negara asing dan masyarakat Indonesia yang sangat menyukai makan daging kodok sehingga memiliki prospek yang cukup cerah dikembangkan sebagai salah satu kuliner pariwisata, selain potensi ikan kulen dan julit. Limbah kodok yang tidak dipakai sebagai bahan makanan manusia dapat dipakai untuk ransum binatang seperti itik dan ayam.

Bagi masyarakat yang kreatif, kulit kodok yang telah terlepas dari badannya bisa diproses menjadi kerupuk kulit kodok. Kepala kodok yang sudah terpisah dapat diambil kelenjar hipofisanya dan dimanfaatkan untuk merangsang kodok dalam pembuahan buatan. Sebagian orang percaya daging kodok dapat menyembuhkan beberapa penyakit dan meningkatkan vitalitas laki-laki. Perubahan dalam cara perawatan tanaman di sawah 
dengan pestisida dan rancun telah mengancam kehidupan kodok hijau Bali ini, dan membuat populasinya di alam bebas menurun drastis.

Karena itu sudah saatnya dilakukan peternakan atau budidaya kodok hijau untuk minimal kebutuhan komsumsi sendiri atau menyelamatkan keberlangsungan dari KTB ini, lebih-lebih bisa memasok untuk kebutuhan pariwisata dan syukur kalau mampu kembali bisa memenuhi kebutuhan ekspor seperti di masa lampau sehingga dapat menambah devisa bagi Negara.

\section{Daftar Pustaka}

Ariani, Risa Panti. 2017. Mengenal Kuliner Bali. (Ed.1, Cet.1.). Depok: Rajawali Pers.

Kusumawati, Rika, Putra, Winkanda Satria. 2013. Resep Masakan Nusantara Favorit dari Aceh Hingga Pариа. Yogyakarta: C.V. Andi Offset.

Pitanatri, Putu Diah Sastri, Putra, I Nyoman Darma. 2016. Wisata Kuliner Atribut Baru Destinasi Ubud. Denpasar: Jagatpress bekerja sama dengan Program Studi Magister Kajian Pariwisata Universitas Udayana.

Remen, I Ketut. 1987. Olah-olahan Paebatan Bali. Tanpa penerbit.

Scarpato, Rosario. 2002. "Gastronomy Studies in search of Hospitality" Journal of Hospitality and Tourism Management, Vol. 9 (2): 1-36.

Surayin, Ida Ayu. 2007. Masakan Bali. Surabaya: Paramita.

Wrasiati, Luh Putu, Wijaya, I Made Anom Sutrisna, Suter, I Ketut, Wiranatha, A.A. Putu Suryawan. 2017. Kuliner Tradisional Bali (Balinese Traditional Kulinary). Denpasar: Udayana University Press.

\section{Studi Internet:}

Anonim. 2012. Kodok Hijau. (serial online). [cited 2017 Ags. 2]. Available from URL: http://jualkodok.blogspot.com/2012/07/ kodok-hijau.html.

Anonim. 2013. Cara Memasang Umpan Katak. (serial online). [cited 2017 Ags. 2]. Available from URL: http://jagoanmancing.blogspot.com/2013/ 02/cara-memasang-umpan-katak.html.

Anonim. 2015. Setahun 500 Ton Kodok Hijau Diekspor, Rp 72 Ribu per Kilo. (serial online). [cited 2017 Ags. 2]. Available from URL: https://www. jpnn.com/news/setahun-500-ton-kodok-hijau-diekspor-rp-72-ribu-perkilo?page $=2$.

Anonim. 2017. Cara Menangkap Katak. (serial online). [cited 2017 Ags. 2]. Available from URL: https://id.wikihow.com/Menangkap-Katak.

Anonim. 2017. Manfaat Daging Kodok: Atasi Kanker Hingga Mani Encer. (serial online). [cited 2017 Ags. 2]. Available from URL: http://detik life.com/tag/kandungan-gizi-daging-kodok/. 
Godam. 2017. Isi Kandungan Gizi Kodok - Komposisi Nutrisi Bahan Makanan. (serial online). [cited 2017 Ags. 2]. Available from URL: http://www.or ganisasi.org/1970/01/isi-kandungan-gizi-kodok-komposisi-nutrisibahan-makanan.html\#.W1loH_lTLcs.

Sriwidi. 2017. Kodok goreng sambal tomat (menu batita). (serial online). [cited 2017 Ags. 2]. Available from URL: https://cookpad.com/id/resep/82965 1-kodok-goreng-sambal-tomat-menu-batita?via =search.

Wibisono, Nuran. 2017. Kodok, Kian Banyak di Meja Makan, Kian Sedikit di Alam Bebas. (serial online). [cited 2017 Ags. 2]. Available from URL: https://tirto.id/kodok-kian-banyak-di-meja-makan-kian-sedikit-di-alambebas-ckVB.

Wijaya, Shirley. 2017. Kodok Goreng Tepung with Butter Sauce. (serial online). [cited 2017 Ags. 2]. Available from URL: https://cookpad.com/id/ resep/4979147-kodok-goreng-tepung91\%8D?via=s earch.

Wikipedia. 2017. Budi Daya. (serial online). [cited 2017 Ags. 2]. Available from URL: https://id.wikipedia.org/wiki/Budi_daya.

Wikipedia. 2017. Kodok dan Katak. (serial online). [cited 2017 Ags. 2]. Available from URL: https://id.wikipedia.org/wiki/Kodok_dan_katak.

Wikipedia. 2017. Peternakan. (serial online). [cited 2017 Ags. 2]. Available from URL: https://id.wikipedia.org/wiki/Peternakan.

\section{Informan:}

1. Nama : I Wayan Sabeh

Alamat : Lingkungan Tengah, Desa Adat Lukluk, Mengwi, Badung, Bali

Umur : 78 tahun

2. Nama : Made Kesiar

Alamat : Lingkungan Badung, Desa Adat Lukluk, Mengwi, Badung, Bali

Umur : $\quad$ : 76 tahun

3. Nama : Ni Nyoman Pineh

Alamat : Lingkungan Badung, Desa Adat Lukluk, Mengwi, Badung, Bali

Umur : : 70 tahun

4. Nama : Wayan Kariawan

Alamat : Lingkungan Badung, Desa Adat Lukluk, Mengwi, Badung, Bali

Umur : $\quad: 54$ tahun

\section{Profil Penulis}

A.A Ketut Sri Candrawati, S.S.,M.A lahir di Br. Anyar, 18 Agustus 1974 adalah dosen D3 Seni Kuliner di Politeknik Internasional Bali. Menyelesaikan Pendidikan Sarjana (S1) di Universitas Warmadewa Fakultas Sastra Bahasa Inggris tahun 1997 dan program Magister (S2) di Universitas Tujuh Belas Agustus 1945 (UNTAG) surabaya Jurusan Administrasi pada tahun 2014, mimiliki kemampuan Bahasa Inggris yang 
baik dan memiliki cukup kemampuan pada bahasa Jerman, Jepang, dan Perancis. Tahun 2007-2013 mengajar Bahasa Inggris di tempat kursus Bahasa Inggris dan SMK Margarana, Tabanan. Mengajar bidang Administrasi di STISIP Margarana, Tabanan.

Ni Nyoman Widani, S.S.,M.Hum lahir di Br. Tegal Gundul, 16 Desember 1968. Menyelesaikan Pendidikan SDN 2 Pekandelan Klungkung Bali 1981, SMPN 2 Klungkung Bali thn 1984, SMEAN Klungkung Bali thn 1987 Pendidikan Diploma 1 Akomodasi Perhotelan di PPLP Dhyana Pura Denpasar thn 1989 Menyelesaikan pendidikan S1 pada Fakultas Sastra Inggris Universitas Warmadewa Denpasar tahun 1998 Pendidikan selanjutnya adalah menyelesaikan pendidikan S2 Magister Ilmu Linguistik di Universitas Warmadewa pada tahun 2017. Memiliki pengalaman dalam mengajarkan bahasa Inggris di berbagai tempat pelatihan dan lembaga pendidikan serta memiliki lembaga pelatihan sendiri yaitu Aladdin English Training. Saat ini tercatat sebagai dosen D3 Seni Kuliner pada Politeknik Internasional Bali. 